Sains Malaysiana 49(2)(2020): 375-382

http://dx.doi.org/10.17576/jsm-2020-4902-15

\title{
The Effect of Intranasal Administration of ACTH Analogue Toward Neural Progenitor/Stem Cells Proliferation after Traumatic Brain Injury
}

(Kesan Administrasi Intranasal Analog ACTH terhadap Proliferasi Neural Progenitor/Sel Stem selepas Kecederaan Trauma Otak)

\section{Michael Lumintang LoE*, RR. Suzy Indharty, Andre Mp SiahaAn, Steven TANdeAn \& Wibi Riawan}

\section{ABSTRACT}

Traumatic brain injury (TBI) is a major health problem because of its high mortality and long-term disability worldwide. Neural progenitor/stem cells (NPSCs) that survive in certain parts of the brain, enable brain to produce new neurons and glia. ACTH ${ }_{4-10}$ Pro $^{8}-G l y^{9}-P_{r o}^{10}$ has a modulation effect on the expression and activation of the BDNF/TrkB system in the hippocampus area. The BDNF/TrkB pathway system is a potential therapeutic target toward NPSCs proliferation after TBI. Thirty male Sprague-Dawley rats were divided into three groups, i.e A=sham-operated controls; $B=T B I$; $C=T B I+$ intranasal $A C T H_{4-10}$ Pro $^{8}-G_{1}{ }^{9}-P^{10}{ }^{10}$ administration. After 24 h, rats' brains were immunohistochemically processed, to observe the number of cells expressing $m B D N F$, TrkB, and SOX2 in the subgranular zone(SGZ) of the hippocampus dentate gyrus(DG). Data were analyzed with SPSS 17, ANOVA, Post Hoc Tukey HSD test, with $p$ value < 0,05. Mean expression of BDNF group $C=16.33 \pm 2.83$ increased significantly compared to group $A=8.33 \pm$ $1.32(p=0.0001)$ and group $B=5.89 \pm 1.69(p=0.0001)$. Mean expression of TrkB group $C=17.00 \pm 1.58$ increased significantly compared to group $A=4.33 \pm 1.73(p=0.0001)$ and group $B=5.89 \pm 2.47(p=0.0001)$, TrkB expression in group B increased insignificantly compared to group $A(p=0.234)$. Mean expression of SOX2 in group $C=12.56 \pm 2.07$ increased significantly compared to group $B=8.89 \pm 2.318(p=0.0001)$ and group $A=4.89 \pm 2.42(p=0.0001)$. ACTH ${ }_{10}$ Pro $^{8}-G l y^{9}-$ Pro $^{10}$ can increase the expression of BDNF and TrkB, and the proliferation of NPSCs in the subgranular zone (SGZ) of the hippocampus dentate gyrus (DG).

Keywords: ACTH; BDNF; neural stem cells; SOX2; TrkB; SEMAX ${ }^{\circledR}$; traumatic brain injury

\section{ABSTRAK}

Kecederaan trauma otak (TBI) adalah masalah kesihatan utama di seluruh dunia kerana kadar motaliti yang tinggi dan kecacatan jangka panjang. Neural progenitor/sel stem (NPSCS) yang bertahan pada bahagian tertentu otak, membolehkan otak menghasilkan sel neuron dan glia baru. ACTH ${ }_{4-10}$ Pro $^{8}-$ Gly $^{9}-$ Pro $^{10}$ mempunyai kesan modulasi pada ekspresi dan pengaktifan sistem BDNF/TrkB di kawasan hipokampus. Sistem BDNF/TrkB merupakan sasaran terapeutik yang berpotensi ke arah proliferasi NPSC selepas TBI. Tiga puluh tikus Sprague-Dawley jantan dibahagikan kepada tiga kumpulan, iaitu $A=$ kawalan negatif; $B=T B I$; $C=T B I+A C T H_{4-10}$ Pro $^{8}-G l y^{9}-$ Pro $^{10}$ intranasal. Selepas 24 jam, otak tikus diproses secara imunohistokimia untuk melihat bilangan sel yang mengekspresikan mBDNF, TrkB, dan SOX2 pada subgranular zone(SGZ) daripada hipokampus dentat girus (DG). Data dianalisis dengan ujian SPSS 17, ANOVA, Post Hoc Tukey HSD, dengan nilai $p<0.05$. Ekspresi BDNF kumpulan $C=16.33 \pm 2.83$ meningkat secara signifikan berbanding kumpulan $A=8.33 \pm 1.32(p=0.0001)$, dan kumpulan $B=5.89 \pm 1.69(p=0.0001)$. Secara keseluruhan ekspresi TrkB kumpulan $C=17.00 \pm 1.58$ meningkat secara signifikan berbanding kumpulan $A=4.33 \pm 1.73(p=0.0001)$ dan kumpulan $B=5.89 \pm 2.47(p=0.0001)$, ekspresi TrkB pada kumpulan B meningkat tidak signifikan dibandingkan dengan kumpulan $A(p=0.234)$. Rata-rata ekspresi SOX2 kumpulan $C=12.56 \pm 2.07$ meningkat secara signifikan dibandingkan dengan kumpulan $B=8.89 \pm 2.318(p=0.0001)$ dan kumpulan $A=4.89 \pm 2.42(p=0.0001) . \quad$ ACTH ${ }_{4-10}$ Pro $^{8}-$ Gly $^{9}-$ Pro $^{10}$ dapat meningkatkan ekspresi BDNF dan TrkB serta meningkatkan proliferasi NPSCs pada zon subgranulr (SGZ) daripada hipokampus dentat girus (DG).

Kata kunci: ACTH; BDNF; kecederaan trauma otak; sel stem neural; SEMAX ${ }^{\circledR}$; SOX2; TrkB

\section{INTRODUCTION}

Traumatic brain injury (TBI) is a major public health problem because of its high mortality and long-term disability worldwide (Carney et al. 2016), which is estimated to be a major cause of death and disability by 2020 (Faried et al. 2017). In the United States there are
3.2-6.5 million people currently live with physical, cognitive, or psychological impairment and 50,000 individuals die due to TBI each year (Centers for Disease Control and Prevention 2015; Seo et al. 2018). Head injury following road traffic collision is more common in low- and middle-income countries, and the proportion of TBIs 
secondary to road traffic collision is likewise greatest in these countries. Meanwhile, the estimated incidence of TBI is highest in regions with higher-quality data, specifically in North America and Europe (Dewan et al. 2018). In Indonesia, severe TBIs range between $6 \%$ and $12 \%$ of all TBI, with mortality ranging between $25 \%$ and $37 \%$ (Faried et al. 2017). TBI data cases in the neurosurgery department H. Adam Malik hospital showed that total TBI cases in 2010 as many as 1627 cases, and 274 cases were TBI requiring surgery.

TBI consists of two phases, primary and secondary injury (Galgano et al. 2017; Prins et al. 2013; Sun 2014). Currently, TBI therapy management is focused on preventing or reducing the duration of secondary injuries, rather than just repairing damage caused by the primary injury. Clinical evidence indicates that the hippocampus is highly susceptible to secondary injury (Rolfe \& Sun 2015). Hippocampal injury is associated with memory deficits and learning abilities (Girgis et al. 2016; Wolf et al. 2017). Cognitive deficits are common following TBI and contribute significantly to disability. The frontal lobes and their related circuitry are particularly vulnerable to traumatic damage; hence executive dysfunction is prevalent (Rabinowitz \& Levin 2014). If there is a damage to the part of the brain, such as the frontal lobe, prefrontal behavioral symptoms might occur (Loe \& Maliawan 2019). This cognitive sequelae is the most severe and long-lasting TBI deficit, it causes inhibition of patient's recovery to normal social function. Improvement of spontaneous cognitive functions may occur but is very limited and rare in two years post-injury (Sun 2014).

Various studies showed that neural progenitor/stem cells (NPSCs) that persist in certain parts of the brain, give the brain the ability to produce new neurons and glia (Gage \& Temple 2013). Research evidence suggests that neurogenesis processes occur in the subventricular zone (SVZ) of the lateral and subgranular zone (SGZ) of the hippocampus dentate gyrus (DG) in adult mice, rats, primates and human brains (Gage \& Temple 2013; Rolfe $\&$ Sun 2015; Sun 2014). Newly formed cells can differentiate into mature functional nerve cells and integrate in neural networks (Lindvall \& Kokaia 2015), including cells involved in cognitive function (Zhang et al. 2008a). Ischemic brain injury stimulates the proliferation of neural progenitor/stem cells (NPSCs) located in SVZ and SGZ in adult rats' brains. Newly formed cells will migrate to areas of the injured brain, which will differentiate into mature nerve cells (Jin et al. 2003). Traumatic brain injury also induces cell proliferation of the hippocampus and ipsilateral SVZ, which persist for at least one year (Zheng et al. 2013) and also induces cell proliferation in the brain cortex which located in white matter of the brain in some contralateral passages (Urrea et al. 2006). Although it is unclear as to what kind of injury that can induce post-TBI neurogenesis, evidence of neurogenesis in the brain injury area, raises hopes for rebuilding damaged tissue by endogenous neural stem cell (NSCs) cells (Urrea et al. 2006; Zheng et al. 2013). NPSCs are available in limited quantities in subventricular zone (SVZ) and hippocampus dentate gyrus (DG); in vivo, NPSC at that location, characterized by expression of SOX2 [SRY (sex determining region Y)-box 2] (Faigle \& Song 2013).

The N-terminal fragment of adrenocorticotropic hormone (ACTH), ACTH4-10, is known to play a role in stimulating attention, learning and memory formation (Koroleva \& Myasoedov 2018). One of the clinically proven neuroprotective agent is $\mathrm{ACTH}_{4-10} \mathrm{Pro}^{8}-\mathrm{Gly}^{9}-\mathrm{Pro}^{10}$ peptide compound (Medvedeva et al. 2013). The $\mathrm{ACTH}_{4}$ ${ }_{10}$ Pro $^{8}$-Gly ${ }^{9}-$ Pro $^{10}$ compound is a heptapeptide with a Met(hionine)-Glu(tamine)-His(tidine)-Phe(nylalanine)Pro(line)-Gly(cine)-Pro(line) with single letter nomenclature MEHFPGP. The heptapeptide compound $\mathrm{ACTH}_{4-10}$ Pro $^{8}-\mathrm{Gly}^{9}-\mathrm{Pro}^{10}$ is an $\mathrm{ACTH}_{4-10}$ analogue which is free from hormonal effects and has a neuro-modulatory effect (Koroleva \& Myasoedov 2018).

This suggests that the neurotropic role of $\mathrm{ACTH}_{4}$ ${ }_{10} \mathrm{Pro}^{8}-\mathrm{Gly}^{9}-\mathrm{Pro}^{10}$ is mediated by stimulation of neurotrophin synthesis (Medvedeva et al. 2013), that enhances the expression of nerve growth factor and brain-derived neurotrophic factor (BDNF) in rat glial basal forebrain cell cultures and in mouse in-vivo receiving $\mathrm{ACTH}_{4-10} \mathrm{Pro}^{8}$-Gly9Pro $^{10}$ intranasal (Agapova et al. 2007), and expression of tropomyosin receptor kinase B (TrkB) in mouse hippocampus (Dolotov et al. 2006). It is concluded that $\mathrm{ACTH}_{4-10}$ Pro $^{8}-\mathrm{Gly}^{9}-\mathrm{Pro}^{10}$ has a modulation effect on the expression and activation of BDNF/TrkB system in the hippocampus area (Dolotov et al. 2006).

mBDNF plays a role in cell proliferation, differentiation, adhesion and maturation, which induces growth, resistance and regeneration of central nervous cells after injury (Numakawa et al. 2010). TrkB is an intracellular receptor tyrosine kinase that has the greatest affinity for mBDNF, which plays a role in various intracellular cascades; TrkB regulates cell growth, differentiation of nerve, and regulating neuronal plasticity (Gupta et al. 2013). TBI is known to cause temporarily and selectively downregulation of TrkB receptors (Conte et al. 2009; Hicks et al. 1998; O'Dell et al. 2000).

The BDNF/TrkB pathway system is a potential therapeutic target toward NPSCs proliferation after TBI. Until now, the effect of $\mathrm{ACTH}_{4-10} \mathrm{Pro}^{8}-\mathrm{Gly}^{9}-\mathrm{Pro}^{10}$ (MEHFPGP) intranasal on the expression of BDNF, TrkB and NPSCs after traumatic brain injury is unknown. Therefore, this study will examine the effect of intranasal administration of $\mathrm{ACTH}_{4-10}$ Pro $^{8}$-Gly ${ }^{9}$ Pro $^{10}$ (MEHFPGP) as a promoter of proliferation of neural progenitor/stem cells (NPSCs) in rat that have traumatic brain injury.

\section{Materials AND Methods}

The study was conducted in accordance with ethics approval from the Ethics Committee, Faculty of Medicine, Universitas Sumatera Utara, Indonesia (No:68/TGL/KEPK FK USU-RSUP HAM/2016). Research and treatment were carried out in the laboratory of pharmacology and biochemistry, Faculty of Medicine, University of Brawijaya, Malang, Indonesia. 


\section{RAT MODEL OF CLOSED HEAD INJURY}

Unilateral focal brain injury was induced on the right cortex using rat model of closed head injury with scalp incision (CHI), performed with the modified Shohami's weight-drop model. Thirty Sprague Dawley rats weighing 250-400 g were randomized into three treatments group, i.e. shamoperated controls, $\mathrm{CHI}$, and CHI with $\mathrm{ACTH}_{4-10} \mathrm{Pro}^{8} \mathrm{Gly}^{9} \mathrm{Pro}^{10}$ $(50 \mu \mathrm{g} / \mathrm{kgBB})$. All rats were given ketamine $\mathrm{HCl}$ (Intramuscular dosage $100 \mathrm{mg} / \mathrm{kg}$ ) and xylazine base concentration $20 \mathrm{mg} / \mathrm{mL}$ (Intramuscular dosage $0.15 \mathrm{~mL} /$ $\mathrm{kg}$ ). The scalp was cleaned with povidone iodine; and aseptic techniques were used throughout surgery. The scalp was opened on the right frontal. Then, the rats were placed securely in stereotactic apparatus. We gave $40 \mathrm{~g}$ metal mass from $1.5 \mathrm{~m}$ height (Figure 1).

Observation was carried out until $24 \mathrm{~h}$ after treatment. Afterward, rats were sacrificed through cervical dislocation after giving ketamine $\mathrm{HCl}(100 \mathrm{mg} /$ $\mathrm{kg}$, intramuscular). The brains were dissected (Figure 2) and post-fixed in $10 \%$ buffered formalin. The specimens were then processed for paraffin-embedded for immunohistochemistry staining preparation. Shamoperated controls rat underwent anaesthesia and surgery, without trauma and treatment.

\section{$\mathrm{ACTH}_{4-10} \mathrm{PRO}^{8} \mathrm{GLY}^{9} \mathrm{PRO}^{10}$ TREATMENT PROTOCOL}

Rats were given $\mathrm{ACTH}_{4-10}$ Pro $^{8}$ Gly $^{9}$ Pro $^{10}$ intranasal application $(50 \mu \mathrm{g} / \mathrm{kgBB})$ once daily. This treatment protocol was based on those used for other studies in which neuronal effect was observed (Agapova et al. 2007).

\section{IMMUNOHISTOCHEMISTRY STAINING}

As neural progenitor/stem cells (NPSCs) proliferation marker, we investigated the expression of mBDNF, TrkB, and SOX2. The expression of all markers were investigated on paraffin-embedded sections using the avidin-biotinperoxidase complex method. Five-micrometer-thick paraffin sections were dewaxed, rehydrated, and microwaved for $10 \mathrm{~min}$. The endogenous peroxidase activity of the investigated specimens was blocked with $3 \% \mathrm{H}_{2} \mathrm{O}_{2}$ for $10 \mathrm{~min}$, followed by $25 \mathrm{~min}$ washing with phosphate-buffered saline (PBS). The tissue sections were incubated with normal rabbit serum for $10 \mathrm{~min}$, and then the slides were incubated at room temperature with monoclonal mouse antibody mBDNF, TrkB, and SOX-2 (Santa Cruz). Sections were washed with PBS and incubated with a secondary antibody for $30 \mathrm{~min}$. Sections were washed twice with PBS, developed with $0.05 \%$ 3,3Diamino-benzinetetrahydrochloride for $5 \mathrm{~min}$, and slightly counterstained.

All samples were evaluated by first author (not blinded to specimen). Positive signal for mBDNF, TrkB, and SOX2 in brain tissue was quantitatively estimated on the basis of distribution of positive stained cells in the sub-granular zone (SGZ) of the hippocampus dentate gyrus (DG) in right brain hemisphere. The number of positive cells are counted
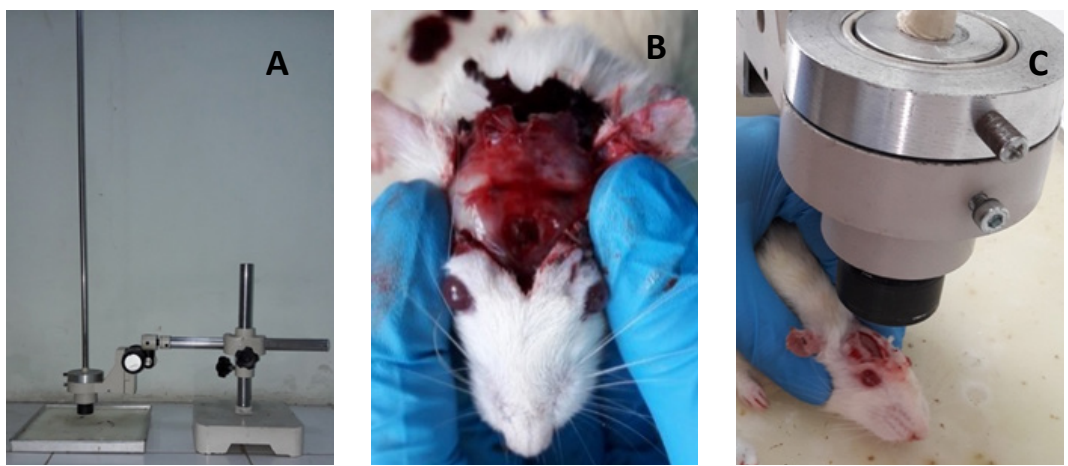

FIGURE 1. Animal model. A. Modified Shohami's weight-drop model; B. Closed head injury (CHI) with scalp incision; C. Rat after injury

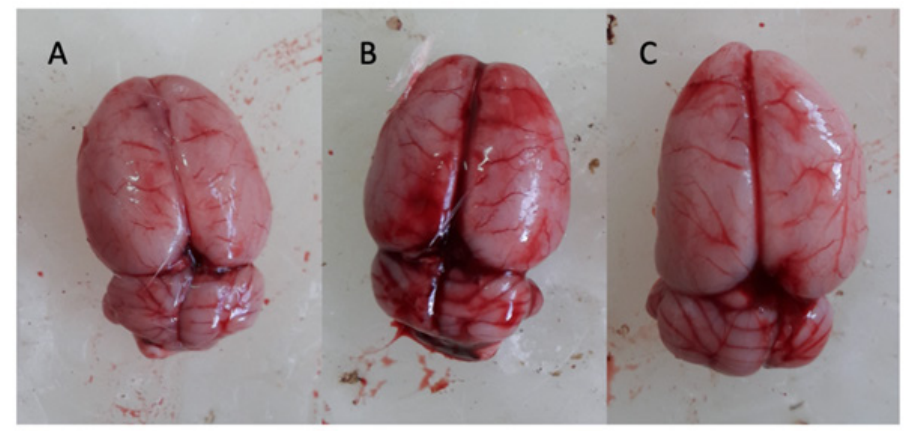

FIGURE 2. Rats' brains. A. sham-operated control group. B. CHI group. C. CHI $+\mathrm{ACTH}_{4-10} \mathrm{Pro}^{8}-\mathrm{Gly}^{9}-\mathrm{Pro}^{10}$ group 


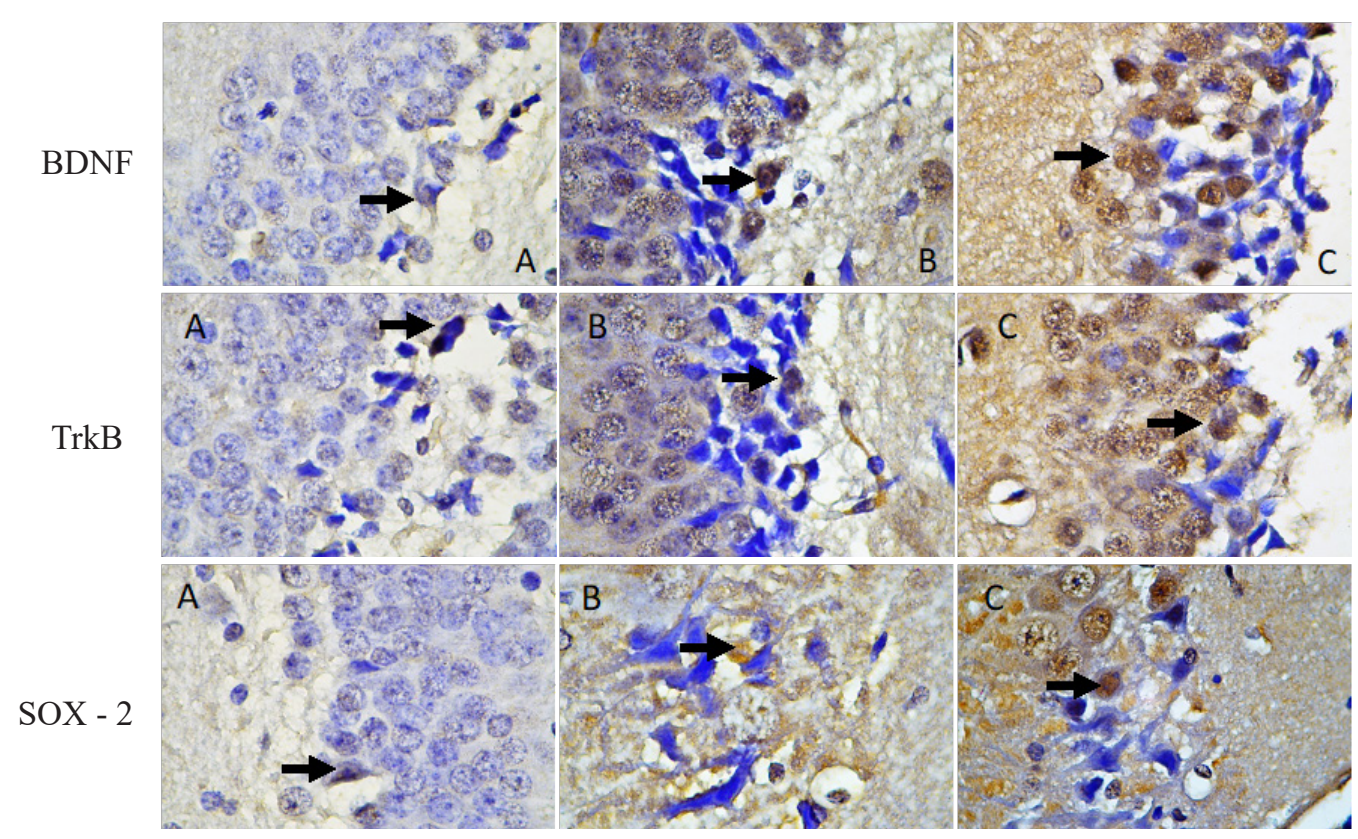

FIGURE 3. Expression of mBDNF, TrkB, and SOX-2 in brain tissue $24 \mathrm{~h}$ after CHI; A. sham-operated control group; B. CHI group; C. CHI+ $\mathrm{ACTH}_{4-10} \mathrm{Pro}^{8}-\mathrm{Gly}^{9}-\mathrm{Pro}^{10}$ group

using light binocular microscope with 1000 times magnification in twenty high power fields.

\section{Statistical Analysis}

The total stained cells were reported in mean and standard deviation. When comparisons were made between groups, significance in between-group variability was analyzed using the one-way ANOVA test with Tuckey as post hoc test. Differences were considered significant at the $P<0.05$.

\section{RESULTS}

Thirty rats were included in this research, divided into three groups, i.e. sham-operated controls, CHI, and $\mathrm{CHI}+\mathrm{ACTH}_{4-10}$ Pro $^{8} \mathrm{Gly}^{9}$ Pro $^{10}$. $\mathrm{ACTH}_{4-10}$ Pro $^{8} \mathrm{Gly}^{9}$ Pro $^{10}$ was given once daily. During the follow up, two rats died directly after trauma procedure. The brain was removed after craniocervical dislocation (Figure 2).

\section{EXPRESSION OF MBDNF, TRKB, AND SOX-2 AFTER TBI}

Immunohistochemistry were used to detect the expression of mBDNF, TrkB, and SOX-2 in brain tissue $24 \mathrm{~h}$ after CHI. As expected mBDNF, TrkB, and SOX-2 were localized to the nucleus. All of the immunopositive cells were present in the dentate gyrus (Right brain hemisphere) (Figure 3).

The mean of immunopositive cells to mBDNF (Figure 4) in sham-operated controls was $8.33 \pm 1.32$ and in $\mathrm{CHI}$ was 5.89 $\pm 1,69$; it was significantly downregulated in CHI group ( $\mathrm{p}=0.047)$. In addition, the mean of immunopositive cells to TrkB (Figure 5) in sham-operated controls was $4.33 \pm 1,73$ and in CHI was 5.89 $\pm 2,47$. It was not significantly upregulated in CHI group $(p=0.234)$. The mean of immunopositive cells to SOX-2 in sham-operated controls was $4,89 \pm 2,42$ and in CHI was $8,89 \pm 2,31$. It was significantly upregulated in CHI group $(\mathrm{p}=0.003)$ (Figure 6 ). We found that mBDNF and SOX-2 were significantly upregulated in $\mathrm{CHI}$ group compared to sham-operated group $(\mathrm{p}<0.05)$.

\section{$\mathrm{ACTH}_{4-10} \mathrm{PRO}^{8} \mathrm{GLY}^{9} \mathrm{PRO}^{10}$ MODULATED THE EXPRESSION OF MBDNF, TRKB, AND SOX-2 AFTER TBI}

After $24 \mathrm{~h}$ intranasal application of $\mathrm{ACTH}_{4-10} \mathrm{Pro}^{8} \mathrm{Gly}^{9} \mathrm{Pro}^{10}$, it showed that $\mathrm{ACTH}_{4-10} \mathrm{Pro}^{8} \mathrm{Gly}^{9} \mathrm{Pro}^{10}$ upregulated the expression of $m B D N F$, TrkB, and SOX-2 (Figure 3). The mean of immunopositive cells to $m B D N F$ was $16.33 \pm 2,83$ (Figure 4); TrkB was 17,00 $\pm 1,58$ (Figure 5). It was significantly compared to sham-operated group $(\mathrm{p}=0,0001)$ and CHI group $(\mathrm{p}=0,0001)$. Mean of immunopositive cells to SOX-2 was $12,56 \pm 2,07$. It was significantly compared to sham-operated group $(\mathrm{p}=0,0001)$ and CHI group $(\mathrm{p}=0,006)$ (Figure 6).

TABLE 1. Expression of mBDNF, TrkB and SOX-2 in shamoperated control group, $\mathrm{CHI}$, and $\mathrm{CHI}+\mathrm{ACTH}_{4-10} \mathrm{Pro}_{8}-\mathrm{Gly}_{9}-\mathrm{Pro}_{10}$ group

\begin{tabular}{lccc}
\hline Group & mBDNF & TrkB & SOX-2 \\
\hline $\begin{array}{l}\text { Sham-operated } \\
\text { control }\end{array}$ & $2.44 \pm 1.01$ & $3.33 \pm 1.22$ & $7.33 \pm 1.23$ \\
$\mathrm{CHI}$ & $8.56 \pm 1.24$ & $9.89 \pm 2.26$ & $9.78 \pm 1.56$ \\
$\mathrm{CHI}+\mathrm{ACTH}_{4-}$ & $11.67 \pm 1.94$ & $12.67 \pm 1.80$ & $12.00 \pm$ \\
${ }_{\mathrm{Pro}_{8}-\mathrm{Gly}_{9}{ }^{-}}$ & & & 1.22 \\
Pro $_{10}$ & & & \\
\hline $\mathrm{P}$ & 0.0001 & 0.0001 & 0.0001 \\
\hline
\end{tabular}

One way ANOVA; *significant. CHI Closed head injury 


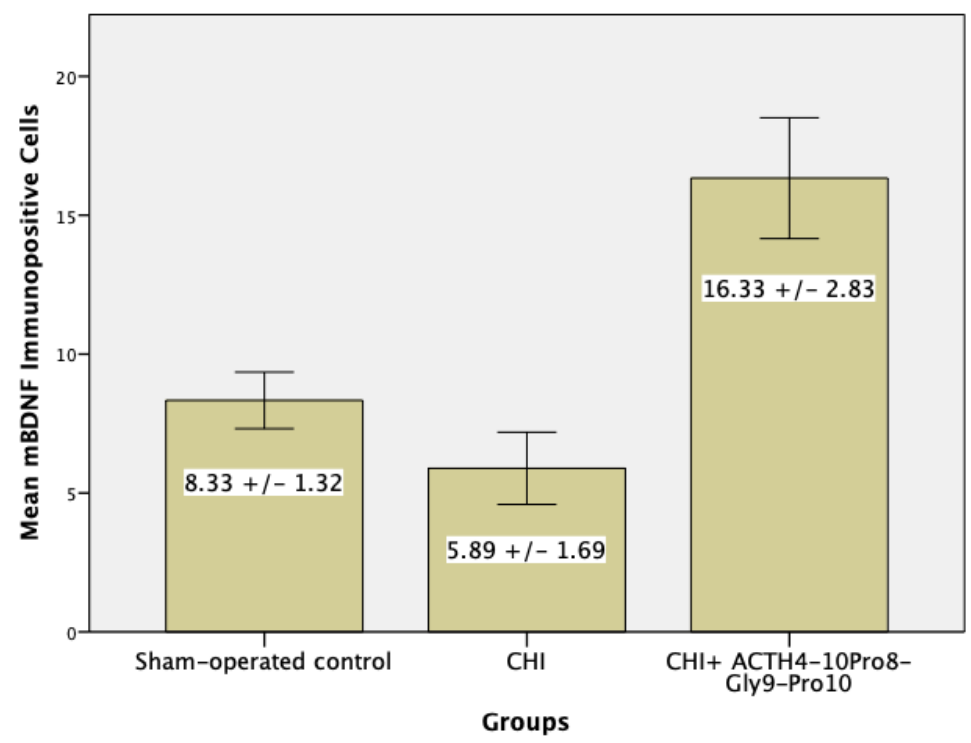

FIGURE 4. Expression of mBDNF in brain tissue $24 \mathrm{~h}$ after $\mathrm{CHI}(* \mathrm{P}<0.05)$

\section{DISCUSSION}

We investigated the effects of $\mathrm{ACTH}_{4-10} \operatorname{Pro}^{8} \mathrm{Gly}^{9} \mathrm{Pro}^{10}$, a promising agent to treat traumatic brain injury in the 'acute phase', on endogenous neural progenitor/stem cells (NPSCs) in vivo using immunohistochemistry. Our data suggested a positive effect of $\mathrm{ACTH}_{4-10} \mathrm{Pro}^{8} \mathrm{Gly}^{9} \mathrm{Pro}^{10}$ on NPSCs proliferation in sub-granular zone (SGZ) in the dentate gyrus (DG) of hippocampus. It was possible because $\mathrm{ACTH}_{4-10} \mathrm{Pro}^{8}-\mathrm{Gly}^{9}-\mathrm{Pro}^{10}$ has a modulation effect on the expression and activation of BDNF/TrkB system in the hippocampus area, by increasing expression of neuronal growth factors and brain-derived neurotropic factors (BDNF) and show tropomyosin kinase B receptors (TrkB) in rat hippocampus (Dolotov et al. 2006).

INTRANASAL ACTH ${ }_{4-10} \mathrm{PRO}^{8}-\mathrm{GLY}^{9}-\mathrm{PRO}^{10}$ (MEHFPGP) INCREASES MBDNF EXPRESSION IN THE SUBGRANULAR ZONE (SGZ) OF THE HIPPOCAMPUS DENTATE GYRUS (DG)

mBDNF plays a role in cell proliferation, differentiation, adhesion and maturation, which induces growth, resistance and regeneration of central nervous cells after injury (Numakawa et al. 2010). Nonexistence of mBDNF after TBI cause significantly neurons death in dentate gyrus (Gao $\&$ Chen 2009). In our study, intranasal administration of $\mathrm{ACTH}_{4-10} \mathrm{Pro}^{8}-\mathrm{Gly}^{9}-\mathrm{Pro}^{10}$ increased mBDNF expression significantly $(\mathrm{p}=0.0001)$ compared to the sham-operated group and the CHI group. This increase occured in the endogenous mBDNF, which is beneficial, because it is different from the exogenous mBDNF, which cannot penetrate the blood-brain barrier (Poduslo \& Curran 1996), very unstable (short half-life) (Zuccato et al. 2011), and can cause cross-activation nociceptors (directly or through p75NTR) and an inflammatory reaction (Zhang et al. 2008b).

However, there was a significant decrease in $\mathrm{mBDNF}$ expression $(\mathrm{p}=0.0001)$ in the $\mathrm{CHI}$ group compared to the sham-operated group. Previous studies in experimental TBI showed that there was shift regional balances in BDNF/ receptor ratios from pro-survival (mBDNF) to pro-apoptotic (pro-BDNF) (Failla et al. 2016). Note that Pro-BDNF binding to $\mathrm{p} 75 \mathrm{NTR}$ associated to sortilin, induces apoptosis (Cacialli et al. 2018) and axonal degeneration (Kaplan et al. 2010).

INTRANASAL ACTH ${ }_{4-10} \mathrm{PRO}^{8}-\mathrm{GLY}^{9}-\mathrm{PRO}^{10}$ (MEHFPGP) INCREASES TRKB EXPRESSION IN THE SUBGRANULAR ZONE (SGZ) OF THE HIPPOCAMPUS DENTATE GYRUS (DG)

Activation of the TrkB receptor that has the greatest affinity for mBDNF (Gupta et al. 2013), has been reported to be associated with enhanced neuronal survival, axonal growth and neuronal plasticity (Atwal et al. 2000). In our study, intranasal administration of $\mathrm{ACTH}_{4-10} \mathrm{Pro}^{8}-\mathrm{Gly}^{9}-\mathrm{Pro}^{10}$ increased TrkB receptor expression significantly $(\mathrm{p}=$ 0.0001) compared to the sham-operated group and the CHI group.

TBI may cause a selective and downregulation of TrkB receptors (Hicks et al. 1998), resulting in an intrinsic inability of hippocampal neurons to respond to neurotrophin (Conte et al. 2009). In contrast to the results of our study, there was no significant increase in TrkB receptor expression $(p=0.234)$ in the CHI group compared to the sham-operated group.

INTRANASAL ACTH ${ }_{4-10} \mathrm{PRO}^{8}-\mathrm{GLY}^{9}-\mathrm{PRO}^{10}$ (MEHFPGP) INCREASES NEURAL PROGENITOR/STEM CELLS (NPSCS) (SOX2) EXPRESSION IN THE SUB-GRANULAR ZONE (SGZ) OF THE HIPPOCAMPUS DENTATE GYRUS (DG)

NPSCs are available in limited quantities in SVZ and DG; in vivo, NPSC at that location, characterized by expression of SOX2 expression (Faigle \& Song 2013). Our finding showed that $\mathrm{ACTH}_{4-10} \mathrm{Pro}^{8} \mathrm{Gly}^{9} \mathrm{Pro}^{10}$ has positive effects on the numbers of NPSCs (SOX2 expression) which increased 


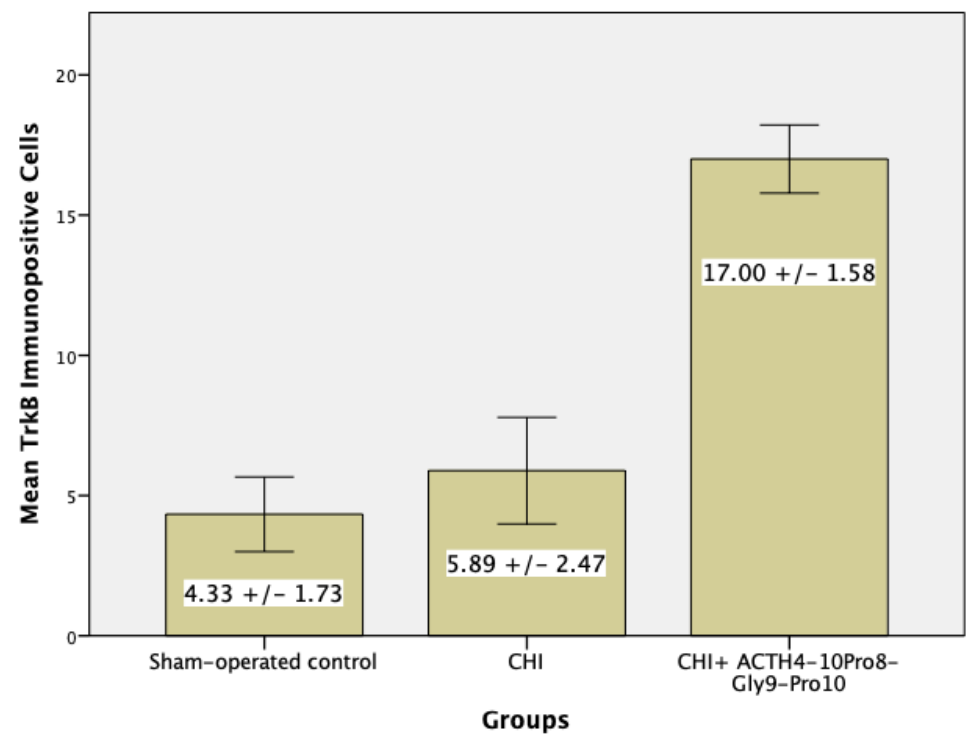

FIGURE 5. Expression of TrkB in brain tissue 24 hours after $\mathrm{CHI}(* \mathrm{P}<0.05$; \# $\mathrm{P}>0.05)$

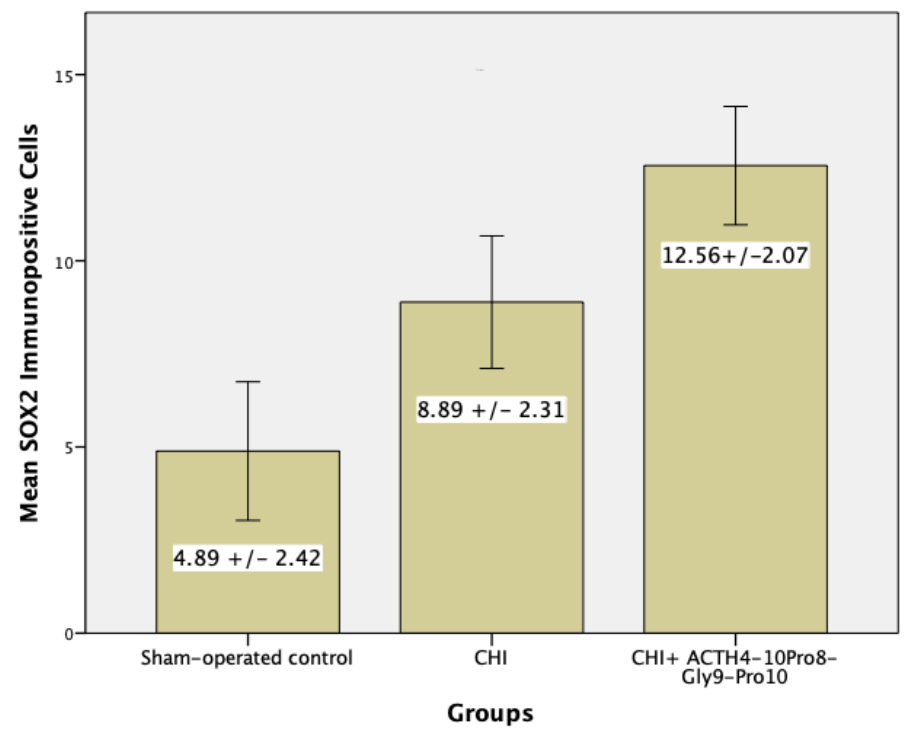

FIGURE 6. Expression of SOX-2 in brain tissue $24 \mathrm{~h}$ after $\mathrm{CHI}(* \mathrm{P}<0.05)$

significantly compared to the sham-operated group $(p=0,0001)$ and the CHI group $(p=0,006)$. This increase, accompanied by increased expression of BDNF and TrkB in the intranasal $\mathrm{ACTH}_{4-10}$ Pro $^{8} \mathrm{Gly}^{9}$ Pro $^{10}$ group, which showed the involvement of BDNF/TrkB pathways in the NPSCs proliferation.

There was a significant increase in the number of cells expressing SOX $2(p=0.0001)$ in the CHI group compared to the sham-operated control, indicating an increase in NPSCs proliferation after TBI. It was known that TBI induces proliferation of astrocytes and neural progenitor/ stem cells (Sandhir et al. 2008).

\section{CONCLUSION}

We found that $\mathrm{ACTH}_{4-10} \mathrm{Pro}^{8}-\mathrm{Gly}^{9}-\mathrm{Pro}^{10}$ (MEHFPGP) as a promising candidate in traumatic brain injury therapy, has a direct positive effect on the proliferation of endogenous NPSCs in the sub-granular zone (SGZ) of the hippocampus dentate gyrus (DG), through BDNF/TrkB pathways system. This increases the possibility of developing therapeutic strategies in acute phase, which aims in harnessing neurogenic capacity to repopulate and repair the damaged brain due to traumatic brain injury, for brain function repair.

\section{ACKNOWLEDGEMENTS}

There are no conflicts of interest and financial disclosures to report.

\section{REFERENCES}

Agapova, T.Y., Agniullin, Y.V., Shadrina, M.I., Shram, S.I., Slominsky, P.A., Lymborska, S.A. \& Myasoedov, N.F. 
2007. Neurotrophin gene expression in rat brain under the action of semax, an analogue of $\mathrm{ACTH}_{4-10}$. Neuroscience Letters 417(2): 201-205.

Atwal, J.K., Massie, B., Miller, F.D. \& Kaplan, D.R. 2000. The TrkB-Shc site signals neuronal survival and local axon growth via MEK and P13-Kinase. Neuron 27(2): 265-277.

Cacialli, P., Palladino, A. \& Lucini, C. 2018. Role of brainderived neurotrophic factor during the regenerative response after traumatic brain injury in adult zebrafish. Neural Regeneration Research 13(6): 941-944.

Carney, N., Totten, A.M., O’Reilly, C., Ullman, J.S., Hawryluk, G.W.J., Bell, M.J., Bratton, S.L., Chesnut, R., Harris, O.A., Kissoon, N., Rubiano, A.M., Shutter, L., Tasker, R.C., Vavilala, M.S., Wilberger, J., Wright, D.W. \& Ghajar, J. 2016. Guidelines for the Management of Severe Traumatic Brain Injury. 4th ed. New York: Brain Trauma Foundation. p. 244.

Centers for Disease Control and Prevention. 2015. Report to Congress on Traumatic Brain Injury in the United States: Epidemiology and Rehabilitation. Atlanta, GA: National Center for Injury Prevention and Control; Division of Unintentional Injury Prevention.

Conte, V., Raghupathi, R., Watson, D.J., Fujimoto, S., Royo, C., Marklund, N., Stocchetti, N. \& McIntosh, T.K. 2009. TrkB gene transfer does not alter hippocampal neuronal loss and cognitive deficits following traumatic brain injury in mice. Restor. Neurol. Neurosci. 26(1): 45-56.

Dewan, M.C., Rattani, A., Gupta, S., Baticulon, R.E., Hung, Y-C., Punchak, M., Agrawal, A., Adeleye, A.O., Shrime, M.G., Rubiano, A.M. \& Rosenfeld, J.V. 2018. Estimating the global incidence of traumatic brain injury. Journal of Neurosurgery 130(4): 1080-1097.

Dolotov, O.V., Karpenko, E.A., Inozemtseva, L.S., Seredenina, T.S., Levitskaya, N.G., Rozyczka, J., Dubynina, E.V., Novosadova, E.V., Andreeva, L.A., Alfeeva, L.Y., Kamensky, A.A., Grivennikov, I.A., Myasoedov, N.F. \& Engele, J. 2006. Semax, an Analog of ACTH(4-10) with cognitive effects, regulates BDNF and TrkB Expression in the rat hippocampus. Brain Research 1117(1): 54-60.

Faigle, R. \& Song, H.J. 2013. Signaling mechanisms regulating adult neural stem cells and neurogenesis. Biochimica et Biophysica Acta(BBA) - General Subjects 1830(2): 24352448. https://doi.org/10.1016/j.bbagen.2012.09.002.

Failla, M.D., Conley, Y.P. \& Wagner, A.K. 2016. Brain-derived neurotrophic factor (BDNF) in traumatic brain injuryrelated mortality: Interrelationships between genetics and acute systemic and central nervous system BDNF profiles. Neurorehabilitation and Neural Repair 30(1): 83-93.

Faried, A., Bachani, A.M., Sendjaja, A.N., Hung, Y.W. \& Arifin, M.Z. 2017. Characteristics of moderate and severe traumatic brain injury of motorcycle crashes in Bandung, Indonesia. World Neurosurgery 100(4): 195-200. https:// doi.org/10.1016/j.wneu.2016.12.133.

Gage, F.H. \& Temple, S. 2013. Neural stem cells: Generating and regenerating the brain. Neuron 80(3): 588-601. https:// doi.org/10.1016/j.neuron.2013.10.037.

Galgano, M., Toshkezi, G., Qiu, X.C., Russell, T., Chin, L. \& Zhao, L-R. 2017. Traumatic brain injury: Current treatment strategies and future endeavors. Cell Transplantation 26(7): 1118-1130.

Gao, X. \& Chen, J.H. 2009. Conditional knockout of brainderived neurotrophic factor in the hippocampus increases death of adult-born immature neurons following traumatic brain injury. Journal of Neurotrauma 26(8): 1325-1335.
Girgis, F., Pace, J., Sweet, J. \& Miller, J.P. 2016. Hippocampal neurophysiologic changes after mild traumatic brain injury and potential neuromodulation treatment approaches. Frontiers in Systems Neuroscience 10 (February). https:// doi.org/10.3389/fnsys.2016.00008.

Gupta, V., You, Y., Gupta, V., Klistorner, A. \& Graham, S. 2013. TrkB receptor signalling: Implications in neurodegenerative, psychiatric and proliferative disorders. International Journal of Molecular Sciences 14(5): 10122-10142.

Hicks, R.R., Zhang, L., Dhillon, H.S., Prasad, M.R. \& Seroogy, K.B. 1998. Expression of TrkB MRNA is altered in rat hippocampus after experimental brain trauma. Molecular Brain Research 59(2): 264-268.

Jin, K.L., Sun, Y.J., Xie, L., Peel, A., Mao, X.O., Batteur, S. \& Greenberg, D.A. 2003. Directed migration of neuronal precursors into the ischemic cerebral cortex and striatum. Molecular and Cellular Neuroscience 24(1): 171-189. https://doi.org/10.1016/S1044-7431(03)00159-3.

Kaplan, G.B., Vasterling, J.J. \& Vedak, P.C. 2010. Brainderived neurotrophic factor in traumatic brain injury, posttraumatic stress disorder, and their comorbid conditions: Role in pathogenesis and treatment. Behavioural Pharmacology 21(5-6): 427-437. https://doi.org/10.1097/ FBP.0b013e32833d8bc9.

Koroleva, S.V. \& Myasoedov, N.F. 2018. Semax as a universal drug for therapy and research. Biology Bulletin 45(6): 589600. https://doi.org/10.1134/S1062359018060055.

Lindvall, O. \& Kokaia, Z. 2015. Neurogenesis following stroke affecting the adult brain. Cold Spring Harb. Perspect. Biol. 7(11): a019034.

Loe, M.L. \& Maliawan, S. 2019. Spontaneous recovery of medial prefrontal syndrome following giant olfactory groove meningioma resection: A case report. Bali Medical Journal 8(2): 287-291. https://doi.org/10.15562/bmj.v8i2.1454.

Medvedeva, E.V., Dmitrieva, V.G., Povarova, O.V., Limborska, S.A., Skvortsova, V.I., Myasoedov, F.N. \& Dergunova, L.V. 2013. Effect of Semax and its C-Terminal fragment ProGly-Pro on the expression of VEGF family genes and their receptors in experimental focal ischemia of the rat brain. Journal of Molecular Neuroscience 49(2): 328-333. https:// doi.org/10.1007/s12031-012-9853-y.

Numakawa, T., Suzuki, S., Kumamaru, E., Adachi, N., Richards, M. \& Kunugi, H. 2010. BDNF function and intracellular signaling in neurons. Histol. Histopathol. 25: 237-258.

O’Dell, D.M., Raghupathi, R., Crino, P.B., Eberwine, J.H. \& McIntosh, T.K. 2000. Traumatic brain injury alters the molecular fingerprint of TUNEL-positive cortical neurons in vivo: A single-cell analysis. The Journal of Neuroscience: The Official Journal of the Society for Neuroscience 20(13): 4821-4828.

Poduslo, J.F. \& Curran, G.L. 1996. Permeability at the bloodbrain and blood-nerve barriers of the neurotrophic factors: NGF, CNTF, NT-3, BDNF. Molecular Brain Research 36(2): 280-286.

Prins, M., Greco, T., Alexander, D. \& Giza, C.C. 2013. The pathophysiology of traumatic brain injury at a glance. Disease Models \& Mechanisms 6(6): 1307-1315.

Rabinowitz, A.R. \& Levin, H.S. 2014. Cognitive sequelae of traumatic brain injury. The Psychiatric Clinics of North America 37(1): 1-11.

Rolfe, A. \& Sun, D. 2015. Stem cell therapy in brain trauma: Implications for repair and regeneration of injured brain in experimental TBI models. In Brain Neurotrauma: Molecular, Neuropsychological, and Rehabilitation Aspects, 
edited by Kobeissy, F.H. Boca Raton: CRC Press/Taylor \& Francis.

Sandhir, R., Onyszchuk, G. \& Berman, N.E.J. 2008. Exacerbated glial response in the aged mouse hippocampus following controlled cortical impact injury. Experimental Neurology 213(2): 372-380

Seo, D.E., Shin, S.D., Song, K.J., Ro, Y.S., Hong, K.J. \& Park, J.H. 2018. Effect of hypoxia on mortality and disability in traumatic brain injury according to shock status: A cross-sectional analysis. The American Journal of Emergency Medicine 12: S0735675718309847. https://doi. org/10.1016/j.ajem.2018.12.022.

Sun, D. 2014. The potential of endogenous neurogenesis for brain repair and regeneration following traumatic brain injury. Neural Regeneration Research 9(7): 688-692.

Urrea, C., Castellanos, D.A., Sagen, J., Tsoulfas, P., Bramlett, H.M. \& Dietrich, W.D. 2006. Widespread cellular proliferation and focal neurogenesis after traumatic brain injury in the rat. Res. Neurology and Neuroscience 25: 6576.

Wolf, J.A., Johnson, B.N., Johnson, V.E., Putt, M.E., Browne, K.D., Mietus, C.J., Brown, D.P., Wofford, K.L., Smith, D.H., Grady, M.S., Cohen, A.S. \& Cullen, D.K. 2017. Concussion induces hippocampal circuitry disruption in swine. Journal of Neurotrauma 34(14): 2303-2314. https:// doi.org/10.1089/neu.2016.4848.

Zhang, C-L., Zou, Y.H., He, W.M., Gage, F.H. \& Evans, R.M. 2008. A role for adult TLX-positive neural stem cells in learning and behaviour. Nature 451(7181): 1004-1007. https://doi.org/10.1038/nature06562.

Zhang, Y.H., Xian, X.C. \& Nicol, G.D. 2008. Brain-derived neurotrophic factor enhances the excitability of rat sensory neurons through activation of the P75 neurotrophin receptor and the sphingomyelin pathway. The Journal of Physiology 586(13): 3113-3127. https://doi.org/10.1113/ jphysiol.2008.152439.
Zheng, W.M., ZhuGe, Q.C., Zhong, M., Chen, G.R., Shao, B., Wang, H., Mao, X.O., Xie, L., \& Jin, K.L. 2013. Neurogenesis in adult human brain after traumatic brain injury. Journal of Neurotrauma 30(22): 1872-1880. https:// doi.org/10.1089/neu.2010.1579.

Zuccato, C., Marullo, M., Vitali, B., Tarditi, A., Mariotti, C., Valenza, M., Lahiri, N., Wild, E.J., Sassone, J., Ciammola, A., Bachoud-Lèvi, A.C., Tabrizi, S.J., Di Donato, S. \& Cattaneo, E. 2011. Brain-derived neurotrophic factor in patients with Huntington's Disease. PLoS ONE 6(8): e22966. https://doi. org/10.1371/journal.pone.0022966.

Michael Lumintang Loe*, Rr. Suzy Indharty, Andre MP Siahaan $\&$ Steven Tandean

Department of Neurosurgery

Faculty of Medicine

Universitas Sumatera Utara/Haji Adam Malik General Hospital

Medan 20155

Indonesia

Wibi Riawan

Department of Biochemistry

Faculty of Medicine

University of Brawijaya

Malang 65145

Indonesia

*Corresponding author; email: dr.michael.lumintang@gmail. com

Received: 7 September 2019

Accepted: 24 October 2019 